\title{
Pengaruh Komposisi Biochar dalam Kompos sebagai Bahan Pupuk Dasar dan sebagai Bahan Dasar Aplikasi Teh Kompos terhadap Pertumbuhan dan Hasil Bawang Putih (Allium Sativum L) Siung Tunggal
}

\author{
Maria Yasintha Moti Fretis ${ }^{a}$, Krisantus Tri Pambudi Raharjo ${ }^{\text {b, }}$ Eduardus Yosef Neonbeni ${ }^{c}$ \\ ${ }^{a}$ Fakultas Pertanian, Universitas Timor, Kefamenanu, TTU - NTT, Indonesia, email: mariayasinthafretis@gmail.com \\ ${ }^{b}$ Fakultas Pertanian, Universitas Timor, Kefamenanu,TTU-NTT, Indonesia, email:initriraharjaa@gmail.com \\ ${ }^{c}$ Fakultas Pertanian, Universitas Timor, Kefamenanu, TTU - NTT, Indonesia, email: ambeni02@gmail.com
}

\section{Article Info}

Article history:

Received in revised form 9 Maret 2019 Accepted 27 Maret 2019

$D O I:$

https://doi.org/10.32938/sc.v4i02.611

\section{Keywords:}

Biochar

Bawang Putih

Teh Kompos
Received 8 Desember 2018

\section{Abstrak}

Bawang putih umbi siung tunggal memiliki harga dan prospek ekonomi yang relatif lebih tinggi dibanding umbi siung majemuk. Hasil penelitian sebelumnya menunjukkan bahwa menurunnya keterbatasan ruang tumbuh dan sumberdaya, meningkatkan pembentukan bawang putih umbi siung tunggal. Penelitian ini telah dilaksanakan pada bulan Mei sampai September 2018 di kebun praktek Fakultas Pertanian Universitas Timor. Tujuan penelitian yakni untuk menguji pengaruh komposisi biochar dalam kompos dan teh kompos biochar terhadap pertumbuhan dan hasil bawang putih siung tunggal di dataran menengah, yang menggunakan rancangan acak kelompok faktorial 3 x 3 diulang 3 kali. Faktor pertama adalah komposisi biochar dalam kompos (B) terdiri dari 3 aras, yaitu: kompos murni $\left(\mathrm{B}_{0}\right)$, kompos+ biochar $10 \%\left(\mathrm{~B}_{1}\right)$, kompos + biochar $20 \%\left(\mathrm{~B}_{2}\right)$. Bahan dari faktor pertama kemudian diterapkan sebagai faktor kedua sebagai jenis teh kompos $(\mathrm{T})$ terdiri dari 3 aras yaitu: tanpa teh kompos $\left(\mathrm{T}_{0}\right)$ teh kompos murni $\left(\mathrm{T}_{1}\right)$, teh kompos biochar $\left(\mathrm{T}_{2}\right)$, dengan demikian terdapat 9 petak kombinasi perlakuan yaitu; $\mathrm{B}_{0} \mathrm{~T}_{0}, \mathrm{~B}_{0} \mathrm{~T}_{1}, \mathrm{~B}_{0} \mathrm{~T}_{2}, \mathrm{~B}_{1} \mathrm{~T}_{0}, \mathrm{~B}_{1} \mathrm{~T}_{1}, \mathrm{~B}_{1} \mathrm{~T}_{2}, \mathrm{~B}_{2} \mathrm{~T}_{0}, \mathrm{~B}_{2} \mathrm{~T}_{1}$, dan $\mathrm{B}_{2} \mathrm{~T}_{2}$, dalam 3 blok sehingga terdapat 27 petak ditambah 3 petak perlakuan kontrol sehingga seluruhnya terdapat 30 petak percobaan. Hasil Penelitian menunjukkan pemberian kompos+biochar $20 \%$ dan teh kompos + biochar berinteraksi secara positif $(\mathrm{P}<0.05)$ terhadap ketersediaan bahan organik tanah, NTotal, Fosfor (P), Kalium (K) dan KapasitasTukar Kation (KPK). Pemberian kompos biochar $10 \%$ dan teh kompos biochar meningkatkan bobot kering siung tunggal per umbi.

\section{Pendahuluan}

Bawang putih (Allium sativum L) merupakan tanaman daerah dataran tinggi yang bernilai ekonomis tinggi, karena selain sebagai bumbu dapur wajib, laporan sebelumnya menyebutkan sangat berguna bagi kesehatan (Untari, 2010, Prasontodkk.,2017), karena kandungan senyawa kimia organik bermanfaat di dalamnya (Untari, 2010; Wibowo, 2007). Bawang putih siung tunggal terbentuk secara tidak sengaja karena cekaman lingkungan penanaman yang kurang baik, seperti cekaman kekeringan, cekaman ruang tumbuh akibat adanya gulma yang tidak disiangi dan lain-lain. Bawang siung tunggal di daerah kabupaten Timor Tenggah Utara dikenal dengan nama Peob Kata Mese cukup banyak ditemukan di kecamatan Miomaffo Barat kabupaten Timor Tengah Utara (TTU). Umbi dari tanaman bawang siung tunggal ini hanya berisi satu umbi utuh yang kecil. Hal ini disebabkan karena bawang ini hanya membungkus umbi utuh tersebut, sehingga kulit umbi utuh lebih tebal dari pada kulit luar umbi yang bersiung majemuk (Syamsiah dan Tajudin,2005).

Walaupun ukuran umbi siung tunggal relatif kecil namun karena memiliki beragam manfaat bagi kesehatan, sehingga tetap laku di pasaran terutama bagi para peracik jamu dan obat herbal tradisional (Mutmainah, 2016). Oleh karena ukuran umbi yang kecil tersebut, dan untuk memenuhi kebutuhan konsumen diperlukan upaya meningkatkan produksi bawang siung tunggal baik secara kuantitas maupun kualitasnya. Beberapa hasil penelitian membuktikan bahwa produksi bawang siung tunggal dapat ditingkatkan jumlahnya dengan cara menanam siung bagian terdalam dengan jumlah 3 siung per lubang tanam (Kosat, 2013) dan jarak tanam 5 x $5 \mathrm{~cm}$ meningkatkan pembentukan siung tunggal terbanyak. Jarak tanam yang terlalu rapat dan jumlah siung per lubang tanam lebih dari satu akan menghasilkan umbi yang relatif kecil walaupun hasil persatuan luas meningkat (Alib, 2013). Permasalahan yang perlu dipecahkan adalah bagaimana upaya meningkatkan ukuran umbi bawang siung tunggal yang masih relatif kecil menjadi lebih besar lagi. Diasumsikan bahwa dengan teknik budidaya yang tepat, misalnya penggunaan pupuk kompos, baik pada maupun cair pada takaran dan dosis yang tepat dapat mencapai tujuan itu tanpa terjadinya pembentukan siung ganda.

Kondisi di wilayah kabupaten TTU banyak tersebar tanah entisol yang berbatu dan padat disertai tingkat penguapan lebih tinggi dibandingkan dengan daya infiltrasinya. Tanah tersebut juga mudah mengalami erosi, sehingga menyebabkan mudah tercucinya bahan organik dan unsur-unsur haranya dan karenanya perlu upaya konservasi tanah, yakni dengan meningkatkan dan memelihara kesuburan tanah, salah satu upayanya melalui aplikasi kompos yang ditambahkan biochar atau kompos biochar (Pohan dkk., 2007). Biocha yang ditambahkan dalam kompos dapat berfungsi sebagai bahan pengikat ai dan unsur hara sehingga tidak mudah hilang baik akibat penguapan yang disebabkan temperatur yang tinggi di lahan kering. Selain itu biochar memilik ruang pori yang banyak sehingga dapat menjadi ruang hidup yang sangat baik bagi populasi mikroorganisme dalam proses pengomposan (Zaylany, 2017) Penambahan unsur hara melalui aplikasi kompos biochar dan teh kompos harus dilakukan secara tepat, dengan memperhatikan komposisi dan aplikasi yang tepat. Teh kompos adalah ekstrak kompos yang kaya akan mikroorganisme yang menguntungkan dan mengandung unsur hara.Teh kompos mengandung sejumlah mikroba seperti Rhizobacteria, Trichoderma, dan Pseudomonas spp dan mampu meningkatkan pertumbuhan dan produksi tanaman (Sylvia, 2004). Tujuan yang ingin dicapai yakni untuk meningkatkan kesuburan tanah dan produksi tanaman budidaya dapat tercapai, termasuk dalam budidaya bawang siung tunggal. Kompos mampu mengembalikan kesuburan tanah melalui perbaikan sifat-sifat fisik, kimia dan biologi tanah (Musnamar, 2003).

\section{Metode}

Penelitian ini dilaksanakan pada bulan Mei sampai dengan bulan September 2018 di kebun praktek Fakultas Pertanian, Universitas Timor. Rancangan yang digunakan dalam penelitian ini yaitu Rancangan Acak Kelompok (RAK) faktorial $3 \times 3$ dengan 3 ulangan. Faktor pertama adalah komposisi biochar dalam kompos (B) terdiri dari 3 aras, yaitu: kompos murni $\left(\mathrm{B}_{0}\right)$, kompos dengan campuran biochar $10 \%\left(\mathrm{~B}_{1}\right)$, kompos dengan campuran biochar $20 \%\left(\mathrm{~B}_{2}\right)$. Bahan hasil pembuatan kompos dari faktor pertama digunakan sebagai bahan dasar untuk pembuatan teh kompos yang merupakan faktor kedua (Jenis teh kompos/T), terdiri dari 3 aras, yaitu: tanpa teh kompos $\left(\mathrm{T}_{0}\right)$ teh kompos murni $\left(\mathrm{T}_{1}\right)$, teh kompos biochar $\left(\mathrm{T}_{2}\right)$. Dengan demikian terdapat 9 petak kombinasi perlakuan yaitu; $\mathrm{B}_{0} \mathrm{~T}_{0}, \mathrm{~B}_{0} \mathrm{~T}_{1}, \mathrm{~B}_{0} \mathrm{~T}_{2}, \mathrm{~B}_{1} \mathrm{~T}_{0}, \mathrm{~B}_{1} \mathrm{~T}_{1}, \mathrm{~B}_{1} \mathrm{~T}_{2}$ $\mathrm{B}_{2} \mathrm{~T}_{0}, \mathrm{~B}_{2} \mathrm{~T}_{1}$, dan $\mathrm{B}_{2} \mathrm{~T}_{2}$, masing-masing diulang dalam 3 blok sehingga terdapat 27 petak.

Pelaksanaan penelitian ini diawali dengan persiapan bibit umbi bawang putih yang dibeli dari petani di desa Noepesu, kecamatan Mutis kabupaten TTU, lalu dipilih umbi yang sehat, kemudian dipilih siung bagian dalam dengan ukuran relatif seragam, permukaan kulit luar licin/mengkilap. Lahan penelitian dibersihkan dari gulma lalu diolah, dibagi dalam 3 blok (ulangan) dan pada masing-masing blok dibuat 9 petak percobaan dengan ukuran $50 \mathrm{~cm} \mathrm{x}$ $50 \mathrm{~cm}$ sehingga terdapat 27 petak percobaan, ditambah 3 petak kontrol (tanpa kompos dan tanpa teh kompos), sehingga total petak percobaan dalam penelitian ini sebanyak 30 petak dengan jarak antar petak $30 \mathrm{~cm}$ dan jarak antar blok $50 \mathrm{~cm}$. Bahan biochar sekam padi yang digunakan dalam penelitian in dibuat melalui proses pembakaran sekam padi dalam kontiki. Pembakaran berlangsung secara lambat hingga semua sekam dalam kontiki menjadi arang (berwarna hitam), lalu segera disiram air untuk menghentikan proses pembakaran sebelum arang sekam habis terbakar menjadi abu. Biochar yang sudah jadi kemudian digunakan sebagai bahan pembuatan kompos dan teh kompos.

Pengamatan meliputi pengamatan analisa kimia bahan penelitian $(\mathrm{C}$ Organik, N total, P, K, C dan analisis kimia tanah (bahan organik dan KTK), kadar lengas tanah, berat volume tanah, luas daun, bobot kering berangkasan, persentase jumlah pembentukan umbi siung tunggal per petak, persentase bobo kering umbi siung tunggal per petak (\%), bobot kering umbi siung tunggal per umbi dan indeks panen. Data hasil pengamatan kemudian dianalisa dengan menggunakan sidik ragam (Anova) Kelompok (RAK) faktorial. Perbandingan rerata perlakuan diuji menggunakan Duncan Multiple Range Test (DMRT) pada taraf $5 \%$ sesuai petunjuk (Gomez dan Gomez, 2010). Analisa data menggunakan program SAS 9.1.

\section{Hasil dan Pembahasan \\ 3.1 Hasil \\ Analisis Kimia Bahan Penelitian}

Hasil analisa kimia tanah sebelum diberi perlakuan kompos tanpa biochar dan kompos biochar sekam padi menunjukkan bahwa C-Organik tanah 2,09\%, N-Total 0,10\%, P 11,15\% dan K 0,98 \%hasil ini menunjukkan bahwa kandungan $\mathrm{P}$ tanah lebih tinggi, sedangkan kandungan $\mathrm{C}$ organik, $\mathrm{N}$ total, dan $\mathrm{K}$, lebih rendah dibanding pada kompos maupun kompos + biochar. Kandungan C-Organik pada kompos tanpa biochar 30,81\%, kompos biochar sekam padi $30,66 \%$, kandungan $\mathrm{N}$-Total pada kompos tanpa biochar $1,84 \%$ sedangkan kompos biochar sekam padi $1,60 \%$. Kandungan $\mathrm{P}$ pada kompos tanpa biochar $2,15 \%$ dan kompos biochar sekam padi $2,18 \%$, Kandungan $\mathrm{K}$ pada kompos tanpa biochar $1,53 \%$ sedangkan kompos biochar sekam padi 1,56\% (Tabel 1). 
Tabel 1. Hasil analisa kimia bahan penelitian

\begin{tabular}{|c|c|c|c|c|}
\hline \multirow{2}{*}{ Kode Sampel } & C Organik & $\mathrm{N}-\mathrm{Tota}$ & & \multirow{2}{*}{$\mathrm{K}(\mathrm{me} / 10 \mathrm{~g})$} \\
\hline & & $\%) \ldots \ldots$. & (ppm) & \\
\hline Tanah & 2,09 & 0,10 & 11,15 & 0,98 \\
\hline Kompos Murni & 30,81 & 1,84 & 2,15 & 1,53 \\
\hline Kompos + Biochar & 30.66 & 1,60 & 2,18 & 1,56 \\
\hline
\end{tabular}

Hasil sidik ragam (Anova) menunjukkan interaksi antara perlakuan komposisi kompos $+\%$ biochar dengan jenis teh kompos terjadi $(\mathrm{P}<0.05)$ pada pengamatan kandungan bahan organik (Tabel 2). Petak yang diberi perlakuan komposisi kompos $+20 \%$ biochar dengan jenis teh kompos + biochar memiliki kandungan bahan organik tertinggi $(4,33 \%)$ berbeda nyata dibanding semua perlakuan lainnya. Hasil sidik ragam (Anova) menunjukkan interaksi antara perlakuan komposisi kompos $+\%$ biochar dengan jenis teh kompos terjadi $(\mathrm{P}<0.05)$ pada pengamatan KTK (Kapasitas Tukar Kation) tanah (Tabel 2). Petak yang diberi perlakuan komposisi kompos $+20 \%$ biochar dengan jenis teh kompos + biochar memiliki nilai KTK tertinggi $(40,23 \mathrm{me} / 100 \mathrm{~g})$ berbeda nyata dibanding semua perlakuan lainnya (Tabel 2).

Tabel 2. Hasil Analisa Kandungan: Bahan Organik dan KTK

\begin{tabular}{|c|c|c|c|c|}
\hline \multirow{2}{*}{$\begin{array}{l}\text { Komposisi Kompos } \\
+\% \text { Biochar }\end{array}$} & \multicolumn{3}{|c|}{ Jenis Teh Kompos } & \multirow[b]{2}{*}{ Rerata } \\
\hline & $\begin{array}{c}\text { Tanpa Teh } \\
\text { Kompos }\end{array}$ & $\begin{array}{c}\text { Teh Kompos } \\
\text { Murni }\end{array}$ & $\begin{array}{c}\text { Teh Kompos } \\
\text { + Biochar }\end{array}$ & \\
\hline \multicolumn{5}{|l|}{ Bahan Organik (\%) } \\
\hline $0 \%$ & $1.20 \mathrm{i}$ & $1.56 \mathrm{~g}$ & $1.86 \mathrm{f}$ & 1.54 \\
\hline $10 \%$ & $1.32 \mathrm{~h}$ & $2.56 \mathrm{~d}$ & $3.88 \mathrm{c}$ & 2.59 \\
\hline $20 \%$ & $2.33 \mathrm{e}$ & $4.09 \mathrm{~b}$ & $4.33 \mathrm{a}$ & 3.58 \\
\hline Rerata & 1.25 & 2.74 & 3.36 & $(+)$ \\
\hline Kontrol & 0.16 & - & - & 0.16 \\
\hline \multicolumn{5}{|l|}{ KTK (me/100g tanah) } \\
\hline $0 \%$ & $40.23 \mathrm{a}$ & $40.23 \mathrm{a}$ & $36.98 \mathrm{~b}$ & 40.23 \\
\hline $10 \%$ & $40.23 \mathrm{a}$ & $36.51 \mathrm{c}$ & $35.58 \mathrm{~d}$ & 38.37 \\
\hline $20 \%$ & $36.98 \mathrm{~b}$ & $35.12 \mathrm{e}$ & $40.23 \mathrm{a}$ & 37.44 \\
\hline Rerata & 38.60 & 37.29 & 37.60 & $(+)$ \\
\hline Kontrol & 38.60 & & - & 38.60 \\
\hline
\end{tabular}

Keterangan: Angka pada baris dan kolom diikuti huruf yang sama menunjukkan beda pada tingkat nyata ( $\alpha$ ) 5\% menurut uji DMRT.(+) terjadi interaksi antar faktor.

\section{Kadar Lengas Tanah}

Hasil sidik ragam (anova) menunjukkan tidak terjadi interaksi antara perlakuankomposisi kompos $+\%$ biochar dan jenis teh kompos terhadap kadar lengas tanah. Pengaruh tunggal pemberian komposisi kompos biochar tidak berbeda nyata, demikian pula pengaruh tunggal perlakuan teh kompos. Pengaruh tunggal perlakuan komposisi kompos $+\%$ biochar $10 \%$ pada pengamatan 75 HST memiliki kadar lengas tanah terendah $(14,91)$ tetapi tidak berbeda nyata dengan taraf perlakuan lainnya. Tanah yang diberikan perlakuan tanpa teh kompos pada pengamatan 75 HST, memiliki kadar lengas tanah terendah $(14,87)$ tetapi tidak berbeda nyata dengan perlakuan lainnya. Tanah pada perlakuan kontrol memiliki kadar lengas terendah pada setiap waktu pengamatan (Tabel 3).

Tabel 3. Kadar Lengas Tanah (\%)

\begin{tabular}{clcccc}
\hline \multirow{2}{*}{$\begin{array}{c}\text { Waktu } \\
\text { Pengamatan }\end{array}$} & Komposisi & \multicolumn{4}{c}{ Jenis Teh Kompos } \\
\cline { 3 - 6 } \begin{tabular}{c} 
(HST) \\
\cline { 3 - 6 }
\end{tabular} & Biochar & Tanpa Teh & Teh Kompos & Teh Kompos & Rerata \\
& $0 \%$ & 14,42 & 15,51 & 15,74 & $15,23 \mathrm{a}$ \\
75 & $10 \%$ & 14,70 & 14,78 & 15,27 & $14,91 \mathrm{a}$ \\
& $20 \%$ & 15,47 & 17,21 & 17,69 & $16,79 \mathrm{a}$ \\
\cline { 2 - 6 } & Rerata & $14,87 \mathrm{a}$ & $15,83 \mathrm{a}$ & $16,23 \mathrm{a}$ & $(-)$ \\
\cline { 2 - 5 } & Kontrol & 14,02 & 12,37 & 14,55 & 13,65 \\
\hline
\end{tabular}

Keterangan: Angka pada baris dan kolom diikuti huruf yang sama menunjukkan beda pada tingkat nyata ( $\alpha$ ) $5 \%$ menurut uji DMRT. (-) tidak terjadi interaksi antar faktor.

\section{Berat Volume Tanah}

Hasil sidik ragam (Anova) menunjukkan tidak terjadi interaksi antara perlakuan komposisi kompos $+\%$ biochar dan jenis teh kompos terhadap berat volume tanah. Pengaruh tunggal pemberian komposisi kompos biochar tidak berbeda nyata, demikian pula pengaruh tunggal perlakuan teh kompos. Pengaruh tunggal perlakuan komposisi kompos $+\%$ biochar $10 \%$ pada memiliki berat volume tanah terendah $(1,53)$ tetapi tidak berbeda nyata dengan taraf perlakuan lainnya. Tanah yang diberikan perlakuan teh kompos biochar memiliki berat volume tanah terendah $(1,48)$ tetapi tidak berbeda nyata dengan perlakuan lainnya. Tanah yang diberikan perlakuan kontrol memiliki berat volume tanah tertinggi (Tabel 4).

\section{Luas Daun}

Hasil sidik ragam (Anova) menunjukkan tidak terjadi interaksi antara perlakuan komposisi kompos $+\%$ biochar dan jenis teh kompos terhadap luas permukaan daun siung bagian dalam. Pengaruh tunggal pemberian komposisi kompos $+\%$ biochar tidak berbeda nyata, demikian pula pengaruh tunggal perlakuan teh kompos.
Tabel 4. Berat Volume Tanah

\begin{tabular}{lcccc}
\hline $\begin{array}{l}\text { Komposisi Kompos } \\
\% \text { Biochar }\end{array}$ & \multicolumn{3}{c}{ Jenis Teh Kompos } & \\
\cline { 2 - 4 } & $\begin{array}{c}\text { Tanpa Teh } \\
\text { Kompos }\end{array}$ & $\begin{array}{c}\text { Teh Kompos } \\
\text { Murni }\end{array}$ & $\begin{array}{c}\text { Teh Kompos } \\
+ \text { Biochar }\end{array}$ & Rerata \\
\hline $0 \%$ & 1,55 & 1,64 & 1,51 & $1,57 \mathrm{a}$ \\
$10 \%$ & 1,49 & 1,77 & 1,34 & $1,53 \mathrm{a}$ \\
$20 \%$ & 1,68 & 1,40 & 1,58 & $1,55 \mathrm{a}$ \\
\hline Rerata & $1,57 \mathrm{a}$ & $1,60 \mathrm{a}$ & $1,48 \mathrm{a}$ & $(-)$ \\
Kontrol & 2,09 & 1,67 & 1,62 & $1,79 \mathrm{a}$ \\
\hline Keterangan: & Angka pada baris dan kolom diikuti huruf yang sama menunjukkan beda
\end{tabular}

pada tingkat nyata ( $\alpha$ ) 5\% menurut ujiDMRT. (-) tidak terjadi interaksi antar faktor.

Pengaruh tunggal perlakuan komposisi kompos $+\%$ biochar $0 \%$ menghasilkan luas daun terluas $\left(124,44 \mathrm{~cm}^{2}\right)$, walaupun tidak berbeda nyata dengan taraf perlakuan lainnya. Tanaman yang diberikan perlakuan tanpa teh kompos menghasilkan daun terluas $\left(119,78 \mathrm{~cm}^{2}\right)$ berbeda nyata dengan perlakuan lainnya. Tanaman dengan perlakuan kontrol menghasilkan daun yang sempit $\left(65,67 \mathrm{~cm}^{2}\right)$ tetapi tidak berbeda nyata dengan perlakuan lainnya (Tabel 5)

Tabel 5. Luas Daun $\left(\mathrm{cm}^{2}\right)$

\begin{tabular}{lcccc}
\hline \multirow{2}{*}{$\begin{array}{l}\text { Komposisi Kompos } \\
+\% \text { Biochar }\end{array}$} & \multicolumn{3}{c}{ Jenis Teh Kompos } & \multirow{2}{*}{ Rerata } \\
\cline { 2 - 4 } & $\begin{array}{c}\text { Tanpa Teh } \\
\text { Kompos }\end{array}$ & $\begin{array}{c}\text { Teh Kompos } \\
\text { Murni }\end{array}$ & $\begin{array}{c}\text { Teh Kompos } \\
+ \text { Biochar }\end{array}$ & \\
\hline $0 \%$ & 117,00 & 117,67 & 138,67 & $124,44 \mathrm{a}$ \\
$10 \%$ & 123,00 & 112,67 & 103,33 & $113,00 \mathrm{a}$ \\
$20 \%$ & 119,33 & 126,00 & 110,67 & $118,67 \mathrm{a}$ \\
Rerata & $119,78 \mathrm{ab}$ & $118,78 \mathrm{~b}$ & $117,56 \mathrm{a}$ & $(-)$ \\
\hline Kontrol & 45,00 & 47,00 & 105,00 & $65,67 \mathrm{a}$
\end{tabular}

Keterangan: Angka pada baris dan kolom diikuti huruf yang sama menunjukkan beda pada tingkat nyata ( $\alpha$ ) $5 \%$ menurut uji DMRT. (-) tidak terjadi interaksi antar faktor.

\section{Bobot Kering Brangkasan}

Hasil sidik ragam (Anova) menunjukkan tidak terjadi interaksi antara perlakuankomposisi kompos $+\%$ biochar dan jenis teh kompos terhadap bobot kering brangkasan. Pengaruh tunggal perlakuan komposisi biochar tidak berbeda nyata, demikian pula pengaruh tunggal perlakuan teh kompos.

Tabel 6. Bobot Kering Brangkasan (g/petak)

\begin{tabular}{lcccc}
\hline \multirow{2}{*}{$\begin{array}{l}\text { Komposisi Kompos } \\
+\% \text { Biochar }\end{array}$} & \multicolumn{3}{c}{ Jenis Teh Kompos } & Rerata \\
\cline { 2 - 4 } & $\begin{array}{c}\text { Tanpa Teh } \\
\text { Kompos }\end{array}$ & $\begin{array}{c}\text { Teh Kompos } \\
\text { Murni }\end{array}$ & $\begin{array}{c}\text { Teh Kompos } \\
+ \text { Biochar }\end{array}$ & \\
\hline $0 \%$ & 5,72 & 7,63 & 7,60 & $6,98 \mathrm{a}$ \\
$10 \%$ & 6,21 & 3,88 & 5,62 & $5,23 \mathrm{a}$ \\
$20 \%$ & 6,04 & 6,34 & 4,88 & $5,75 \mathrm{a}$ \\
\hline Rerata & $5,99 \mathrm{a}$ & $5,95 \mathrm{a}$ & $6,03 \mathrm{a}$ & $(-)$ \\
\hline Kontrol & 6,86 & 4,57 & 7,66 & $6,36 \mathrm{a}$ \\
\hline Keterangan: & Angka pada baris dan kolom diikuti huruf yang sama menunjukkan beda
\end{tabular}

Keterangan: Angka pada baris dan kolom diikuti huruf yang sama menunjukkan beda

pada tingkat nyata ( $\alpha$ ) 5\% menurut uji DMRT. (-) tidak terjadi interaksi antar faktor.

Pengaruh perlakuan komposisi kompos $+\%$ biochar $0 \%$ menghasilkan berat brangkasan terberat $(6,98 \mathrm{gr} /$ petak $)$ tetapi tidak berbeda nyata dengan taraf perlakuan lainnya. Pengaruh tunggal perlakuan teh kompos biochar menghasilkan bobot kering brangkasan/petak sebesar $(6,03$ gr/petak) tetapi tidak berbeda nyata dengan taraf perlakuan lainnya. Tanaman yang diberi perlakuan kontrol menghasilkan berat brangkasan terbanyak kedua $(6,36$ gr/petak) dibanding tanaman yang diberikan perlakuan komposisi Kompos $+\%$ Biochar 10\% dan 20\% (Tabel 6).

\section{Persentase Jumlah Pembentukan Umbi Siung Tunggal/Petak}

Hasil sidik ragam (Anova) menunjukkan tidak terjadi interaksi antara perlakuan komposisi kompos $+\%$ biochar dan jenis teh kompos terhadap persentase jumlah pembentukan umbi siung tunggal/petak. Pengaruh tunggal perlakuan komposisi kompos $+\%$ biochar tidak berbeda nyata, demikian pula pengaruh tunggal perlakuan teh kompos.

Tabel 7. Persentasi Jumlah Pembentukan Umbi Siung Tunggal/Petak

\begin{tabular}{|c|c|c|c|c|}
\hline \multirow[b]{2}{*}{$\begin{array}{l}\text { Komposisi Kompos } \\
+\% \text { Biochar }\end{array}$} & \multicolumn{3}{|c|}{ Jenis Teh Kompos } & \multirow[b]{2}{*}{ Rerata } \\
\hline & $\begin{array}{c}\text { Tanpa Teh } \\
\text { Kompos }\end{array}$ & $\begin{array}{c}\text { Teh Kompos } \\
\text { Murni }\end{array}$ & $\begin{array}{c}\text { Teh Kompos } \\
\text { + Biochar }\end{array}$ & \\
\hline$\overline{0 \%}$ & 49,65 & 51,06 & 41,10 & $47,27 \mathrm{a}$ \\
\hline $10 \%$ & 53,19 & 59,98 & 56,03 & $56,40 \mathrm{a}$ \\
\hline $20 \%$ & 45,39 & 46,81 & 54,61 & $48,94 \mathrm{a}$ \\
\hline Rerata & $49,41 \mathrm{a}$ & $52,62 \mathrm{a}$ & $50,58 \mathrm{a}$ & $(-)$ \\
\hline Kontrol & 97,87 & 82,98 & 57,45 & $79,43 a$ \\
\hline
\end{tabular}

Keterangan: Angka pada baris dan kolom diikuti huruf yang sama menunjukkan beda pada tingkat nyata ( $\alpha$ ) 5\% menurut uji DMRT. (-) tidak terjadi interaksi antar faktor.

Pengaruh tunggal perlakuan kontrol menghasilkan persentase jumlah pembentukan umbi siung tunggal/petak terberat $(79,43 \%)$ tetapi tidak berbeda nyata dengan taraf perlakuan lainnya. Pengaruh tunggal teh kompos murni menghasilkan persentase jumlah pembentukan umbi siung tunggal terbanyak kedua $(59,98 \%)$ tetapi tidak berbeda nyata dengan taraf perlakuan lainnya. 
Tanaman yang diberi perlakuan kompos murni menghasilkan persentase jumlah pembentukan umbi siung tunggal/petak paling sedikit(47,27\%) dibanding tanaman yang diberi perlakuan komposisi kompos $+\%$ biochar $10 \%$ dan $20 \%$ (Tabel 7).

\section{Persentase Bobot Kering umbi Siung Tunggal/Petak}

Hasil sidik ragam (Anova) menunjukkan tidak terjadi interaksi antara perlakuankomposisi kompos $+\%$ biochar dan jenis teh kompos terhadap Persentase Bobot Kering umbi Siung Tunggal/petak. Pengaruh tunggal perlakuan komposisi kompos $+\%$ biochar tidak berbeda nyata, demikian pula pengaruh tunggal perlakuan teh kompos. Pengaruh tunggal perlakuan komposisi kompos $+\%$ biochar $10 \%$ menghasilkan persentase bobot kering umbi siung tunggal/petak tertinggi $(49,02 \%)$ tetapi tidak berbeda nyata dengan taraf perlakuan lainnya. Pengaruh tunggal perlakuan tanpa teh kompos menghasilkan persentase bobot kering umbi siung tunggal/petak tertinggi $(41,89 \%)$ tetapi tidak berbeda nyata dengan taraf perlakuan lainnya. Tanaman yang diberikan perlakuan kontrol menghasilkan persentase bobot kering umbi siung tunggal/petak tertinggi $(69,75 \%)$ dibanding semua tanaman yang diberi perlakuan komposisi kompos $+\%$ biochar dan jenis teh kompos (Tabel 8 ).

Tabel 8. Persentase Bobot Siung Tunggal/Petak

\begin{tabular}{lcccc}
\hline \multirow{2}{*}{$\begin{array}{l}\text { Komposisi Kompos } \\
+\% \text { Biochar }\end{array}$} & \multicolumn{3}{c}{ Jenis Teh Kompos } & \\
\cline { 2 - 4 } & $\begin{array}{c}\text { Tanpa Teh } \\
\text { Kompos }\end{array}$ & $\begin{array}{c}\text { Teh Kompos } \\
\text { Murni }\end{array}$ & $\begin{array}{c}\text { Teh Kompos } \\
\text { + Biochar }\end{array}$ & \\
\hline $0 \%$ & 36,06 & 33,01 & 22,95 & $30,68 \mathrm{a}$ \\
$10 \%$ & 55,18 & 49,48 & 42,40 & $49,02 \mathrm{a}$ \\
$20 \%$ & 34,43 & 30,13 & 39,19 & $34,59 \mathrm{a}$ \\
\hline Rerata & $41,89 \mathrm{a}$ & $37,54 \mathrm{a}$ & $34,85 \mathrm{a}$ & $(-)$ \\
\hline Kontrol & 97,84 & 68,73 & 42,68 & $69,75 \mathrm{a}$ \\
\hline Keterangan: & Angka pada baris &
\end{tabular}

Keterangan: Angka pada baris dan kolom diikuti huruf yang sama menunjukkan beda pada tingkat nyata ( $\alpha$ ) 5\% menurut uji DMRT. (-) tidak terjadi interaksi antar faktor.

\section{Bobot Kering Siung Tunggal/Umbi}

Hasil sidik ragam (Anova) menunjukkan tidak terjadi interaksi antara perlakuan komposisi kompos $+\%$ biochar dan jenis teh kompos terhadap bobot kering siung tunggal/umbi. Pengaruh tunggal perlakuan komposisi kompos $+\%$ biochar tidak berbeda nyata, demikian pula pengaruh tunggal perlakuan teh kompos. Pengaruh tunggal perlakuan komposisi kompos $+\%$ biochar $10 \%$ menghasilkan bobot kering siung tunggal per umbi terberat $(0,70 \mathrm{~g} / \mathrm{umbi})$ tetap tidak berbeda nyata dengan taraf perlakuan lainnya. Pengaruh tunggal perlakuan teh kompos + biochar menghasilkan bobot kering siung tunggal/umbi terberat $(0,71 \mathrm{~g} / \mathrm{umbi})$ tetapi tidak berbeda nyata dengan taraf perlakuan lainnya. Tanaman yang diberikan perlakuan kontrol menghasilkan bobot kering siung tunggal/umbi paling ringan $(0,63 \mathrm{~g} / \mathrm{umbi})$ dibanding semua tanaman yang diberi perlakuan komposisi kompos $+\%$ biochar dan jenis teh kompos (Tabel 9.)

Tabel 9. Bobot Kering Siung Tunggal/Umbi (g/umbi)

\begin{tabular}{lcccc}
\hline \multirow{2}{*}{$\begin{array}{l}\text { Komposisi Kompos } \\
+\% \text { Biochar }\end{array}$} & \multicolumn{3}{c}{ Jenis Teh Kompos } & \\
\cline { 2 - 5 } & $\begin{array}{c}\text { Tanpa Teh } \\
\text { Kompos }\end{array}$ & $\begin{array}{c}\text { TehKompos } \\
\text { Murni }\end{array}$ & $\begin{array}{c}\text { Teh Kompos } \\
+ \text { Biochar }\end{array}$ & Rerata \\
\hline $0 \%$ & 0,65 & 0,73 & 0,69 & $0,69 \mathrm{a}$ \\
$10 \%$ & 0,70 & 0,67 & 0,74 & $0,70 \mathrm{a}$ \\
$20 \%$ & 0,69 & 0,69 & 0,69 & $0,69 \mathrm{a}$ \\
\hline Rerata & $0,68 \mathrm{a}$ & $0,70 \mathrm{a}$ & $0,71 \mathrm{a}$ & $(-)$ \\
\hline Kontrol & 0,62 & 0,62 & 0,64 & $0,63 \mathrm{a}$ \\
\hline
\end{tabular}

Keterangan: Angka pada baris dan kolom diikuti huruf yang sama menunjukkan beda pada tingkat nyata ( $\alpha$ ) 5\% menurut uji DMRT. (-) tidak terjadi interaksi antar faktor

\section{Bobot Kering Umbi Siung Tunggal/Petak}

Hasil sidik ragam (anova) menunjukkan tidak terjadi interaksi antara perlakuan komposisi kompos $+\%$ biochar dan jenis teh kompos terhadap bobot kering umbi siung tunggal/petak. Pengaruh tunggal perlakuan komposisi kompos $+\%$ biochar tidak berbeda nyata, demikian pula pengaruh tunggal perlakuan teh kompos. Pengaruh tunggal perlakuan komposisi kompos $+\%$ biochar $10 \%$ menghasilkan bobot kering umbi siung tunggal/petak terberat $(0,71 \mathrm{t} / \mathrm{ha})$ tetapi tidak berbeda nyata dengan taraf perlakuan lainnya. Pengaruh tunggal perlakuan teh kompos murni menghasilkan bobot kering umbi siung tunggal/petak terberat $(0,66 \mathrm{t} / \mathrm{ha})$ tetapi tidak berbeda nyata dengan taraf perlakuan lainnya. Tanaman yang diberikan perlakuan kontrol menghasilkan bobot kering umbi siung tunggal/petak terberat $(0,77 \mathrm{t} / \mathrm{ha})$ dibanding tanaman yang diberi perlakuan komposisi biochar dan jenis teh kompos (Tabel 10).

\section{Indeks Panen}

Hasil sidik ragam (Anova) menunjukkan tidak terjadi interaksi antara perlakuankomposisi kompos+ \% biochar dan jenis teh kompos terhadap Indeks Panen. komposisi kompos $+\%$ biochar dan jenis teh kompos tidak berpengaruh nyata terhadap indeks panen tetapi tanaman yang tidak diberikan perlakuan komposisi kompos $+\%$ biochar $10 \%$ cenderung memiliki nilai Indeks Panen tertinggi $(76,69)$ dibanding tanaman yang diberikan perlakuan komposisi kompos $+\%$ biochar $0 \%, 10 \%$ dan jenis teh kompos (Tabel 11 ).
Tabel 10. Bobot Kering Umbi Siung Tunggal/Petak (t/ha)

\begin{tabular}{lllll}
\hline \multirow{2}{*}{$\begin{array}{l}\text { Komposisi Kompos } \\
+\% \text { Biochar }\end{array}$} & \multicolumn{4}{c}{ Jenis Teh Kompos } \\
\cline { 2 - 5 } & Kanpa Teh & Teh Kompos & Teh Kompos & Rerata \\
\hline $0 \%$ & 0,58 & 0,66 & 0,49 & $0,58 \mathrm{a}$ \\
$10 \%$ & 0,67 & 0,73 & 0,74 & $0,71 \mathrm{a}$ \\
$20 \%$ & 0,58 & 0,57 & 0,62 & $0,59 \mathrm{a}$ \\
\hline Rerata & $0,61 \mathrm{a}$ & $0,66 \mathrm{a}$ & $0,62 \mathrm{a}$ & $(-)$ \\
\hline Kontrol & 0,92 & 0,73 & 0,66 & $0,77 \mathrm{a}$ \\
\hline
\end{tabular}

Keterangan: Angka pada baris dan kolom diikuti huruf yang sama menunjukkan beda pada tingkat nyata ( $\alpha$ ) $5 \%$ menurut uji DMRT. (-) tidak terjadi interaksi antar faktor.

\section{Tabel 11. Indeks Panen}

\begin{tabular}{lcccc}
\hline \multirow{2}{*}{$\begin{array}{l}\text { Komposisi Kompos } \\
+\% \text { Biochar }\end{array}$} & \multicolumn{3}{c}{ Jenis Teh Kompos } & \multirow{2}{*}{ Rerata } \\
\cline { 2 - 4 } & $\begin{array}{c}\text { Tanpa Teh } \\
\text { Kompos }\end{array}$ & $\begin{array}{c}\text { Teh Kompos } \\
\text { Murni }\end{array}$ & $\begin{array}{c}\text { Teh Kompos } \\
+ \text { Biochar }\end{array}$ & \\
\hline $0 \%$ & 70,59 & 67,98 & 61,74 & $66,77 \mathrm{a}$ \\
$10 \%$ & 72,95 & 82,02 & 75,09 & $76,69 \mathrm{a}$ \\
$20 \%$ & 69,01 & 68,15 & 74,60 & $70,59 \mathrm{a}$ \\
\hline Rerata & $70,85 \mathrm{a}$ & $72,72 \mathrm{a}$ & $70,48 \mathrm{a}$ & $(-)$ \\
\hline Kontrol & 77,06 & 80,06 & 68,26 & $75,13 \mathrm{a}$ \\
\hline Ketrangan
\end{tabular}

Keterangan: Angka pada baris dan kolom diikuti huruf yang sama menunjukkan beda pada tingkat nyata ( $\alpha$ ) 5\% menurut uji DMRT. (-) tidak terjadi interaksi antar faktor.

\subsection{Pembahasan}

Hasil analisa kimia tanah awal (tanah asli) sebelum diberi perlakuan menunjukan bahwa kandungan $\mathrm{P}$ lebih tinggi $(11,15)$ dibanding kandungan $\mathrm{C}$ Organik. Sedangkan kandungan kimia pada kompos murni menunjukan kandungan C-Organik $(30,81)$. Hasil penelitian ini menunjukkan pengaruh interaksi antara perlakuan komposisi kompos+ \% biochar dan jenis teh kompos terjadi secara positif $(\mathrm{P}<0.05)$ pada pengamatan sifat kimia tanah. Pemberian kompos + biochar $20 \%$ dan teh kompos+biochar pada petak perlakuan berpengaruh meningkatkan bahan organik, dan kapasitas tukar kation. Hasil penelitian menunjukkan bahwa dampak dari faktor perlakuan komposisi kompos $+\%$ biochar dan jenis teh kompos terhadap tanaman bawang putih lokal Eban tidak memberikan interaksi pada pengamatan parameter sifat tanah lainnya yaitu suhu tanah, kadar lengas tanah, dan BV tanah. Pertumbuhan tanaman bawang putih yang diberi komposisi kompos+ \% biochar dan jenis teh kompos dalam penelitian ini tidak menunjukan pengaruh yang nyata.

Rata-rata pengaruh utama pemberian komposisi kompos $+\%$ biochar $20 \%$ mengakibatkan kondisi lingkungan tanaman, seperti kadar lengas meningkat dan $\mathrm{pH}$ tanah mendekati netral. Demikian pula pengaruh utama jenis teh kompos tidak menunjukkan beda nyata antar level perlakuan, namun level pemberian teh kompos + biochar mengakibatkan kondisi lingkungan tanaman, seperti kadar lengas meningkat, berat volume tanah rendah dibanding level perlakuan lainnya. Suhu tanah tidak menunjukkan beda yang nyata antar perlakuan, namun suhu lingkungan berfluktuasi, berkisar antara $21,7-29,3^{\circ} \mathrm{C}$ dan suhu tanah dalam penelitian ini berkisar antara 27,14-29,28. Walaupun interaksi antar perlakuan terjadi pada beberapa pengamatan parameter tanah tetapi kondisi tersebut kurang berdampak pada pertumbuhan tanaman. Hasil penelitian menunjukkan bahwa dampak interaksi antar perlakuan komposisi kompos $+\%$ biochar dan jenis teh kompos terhadap tanaman bawang putih lokal Eban tidak terjadi pada pengamatan parameter pertumbuhan. Hal ini tampak nyata pada petak yang diberi perlakuan pemberian komposisi kompos + biochar $0 \%$ justru menghasilkan pertumbuhan daun yang terluas dibandingkan perlakuan lainnya.

Hasil penelitian menunjukkan bahwa parameter yang diamati selama penelitian untuk mendapatkan jumlah siung tunggal terbanyak justru pada perlakuan kontrol yang ditunjukan pada parameter jumlah umbi siung tunggal per petak terbanyak, persentase jumlah umbi siung tunggal per petak, Bobot Panen Umbi siung tunggal per petak, berat kering akar siung tunggal per petak, persentase bobot umbi siung tunggal per petak, bobot kering umbi siung tunggal per petak dibandingkan dengan tanaman bawang putih yang diberi perlakuan komposisi kompos $+\%$ biochar dan jenis teh kompos. Hal ini menunjukkan bahwa pada kondisi cekaman nutrisi pembentukan umbi siung tunggal lebih berpeluang terjadi dibandingkan kondisi kecukupan nutrisi. Selain cekaman nutrisi, pada penelitian ini juga digunakan jarak tanam $5 \mathrm{~cm} \times 10 \mathrm{~cm}$ sehingga terjadi cekaman ruang tumbuh. Hal ini sesuai dengan hasil penelitian Kosat (2013) bahwa penanaman siung terdalam (lapisan 3 dan jumlah 3 siung perlubang tanam memberikan hasil siung tunggal terbanyak. Hasil penelitian ini membuktikan bahwa, walaupun tidak terjadi interaksi antar faktor, tetapi perlakuan komposisi kompos + biochar $10 \%$ yang dikombinasikan dengan teh kompos biochar berpengaruh meningkatkan hasil tanaman pada para meter bobot kering siung tunggal per umbi terberat dan indeks panen teringgi dibanding perlakuan lainnya.

\section{Simpulan}

Berdasarkan hasil penelitian ditemukan bahwa, hasil analisa kimia tanah menunjukkan bahwa perlakuan komposisi kompos $+\%$ biochar $20 \%$ dan teh kompos + biochar berinteraksi secara positif $(\mathrm{P}<0.05)$ dalam mempengaruhi bahan organik, Kapasitas Tukar Kation (KTK) tanah. Tanaman bawang putih lokal Eban tanpa diberi perlakuan (kontrol), memiliki hasil umbi siung tunggal 
tertinggi yang diekspresikan dalam bentuk persentase jumlah pembentukan umbi siung tunggal/petak, bobot kering umbi suing tunggal/petak, dan persentase bobot kering siung tunggal/petak dibandingkan dengan tanaman bawang putih yang diberi aras perlakuan komposisi kompos $+\%$ biochar dengan jenis teh kompos. Walaupun interaksi antar perlakuan komposisi kompos $+\%$ biochar dan jenis teh kompos tidak terjadi dan tidak meningkatkan hasil siung tunggal tanaman bawang putih lokal Eban, tetapi kombinasi perlakuan komposisi kompos $+\%$ biochar $10 \%$ dan teh kompos biochar memberikan hasil yang tertinggi pada bobot kering siung tunggal/umbi.

\section{Pustaka}

Alib, A. 2013. Pengaruh Jarak Tanam dan Jumlah Tanman Perlubang Terhadap Pembentukan Siung Tunggal Bawang Putih Lokal (Allium sativum, L) Skripsi Agroteknologi. Universitas Timor. TTU. NTT.

Gomez, K.A.Gomez A.A.2010. Prosedur Statistik untuk Penelitian Pertanian. Jakarta: UI Press

Kosat, T.Y. 2013. Pengaruh Bagian Siung dan Jumlah Siung Terhadap Pembentukan Bawang Putih Siung Tunggal (Allium sativum, L) Skripsi Agroteknologi. Universitas Timor. TTU. NTT.

Musnamar, E. I. 2005. Pupuk Organik Padat: Pembuatan dan Aplikasi. Penebar Swadaya. Jakarta. 72 hal.

Mutmainah, S. 2016. Induksi Tunas Adventif Bawang Putih Tunggal (Allium sativum) Dengan Penambahan BAP dan NAA Secara Invitr. Skrips Sains dan Teknologi/ Biologi. Universitas Islam Negeri Maulana Malik Ibrahim . Malang

Pohan A. Kanahau D. Ratnawati S. 2007. Program Rintisan dan Akseleras Pemasyarakatan Inovasi Teknologi Pertanian, Kab. Timor Tengah Utara.

Prasonto, D. Riyanti E. Kartika M. 2017. Jurnal Uji Antioksidan Ekstrak Bawang Putih (Allium sativum L)

Syamsiah, I.S. dan Tajudin. 2005. Khasiat dan Manfaat Bawang Putih. Jakarta Agromedia Pust.

Sylvia, E.W., 2004. The effect of compost extract on the yield of strawberries and severity of Botrys cinera. J. suistainable Agric.25

Untari. I. 2010, Bawang Putih sebagai Obat Paling Mujarab bagi Kesehatan. GASTER, 7(1): 547-554.

Wibowo, S. 2007. Budidaya Bawang : Bawang Putih, Bawang Merah, Bawang Bombay. Penebar Swadaya. Jakarta. 212 hal.

Zaylany. M.F. 2017. Skripsi Pengaruh Residu Biochar Terhadap Beberapa Sifat Kimia Tanah dan Pertumbuhan Tanaman Jagung (Zea mays L) Pada Tanah Ultisol Musim Tanam Ke-4. Universitas Lampung. Bandar Lampung. 